\title{
PERAN PEMBIAYAAN QARDL DALAM MENINGKATKAN PENDAPATAN USAHA KECIL MENENGAH (UKM) PADA ANGGOTA BMT MANDIRI SEJAHTERA CABANG DUKUN GRESIK
}

\author{
Reni Wulan Sari \\ Program Studi Ekonomi Syariah Universitas Islam Lamongan \\ E-mail: reniwulansari383@gmail.com \\ Khozainul Ulum \\ Program Studi Ekonomi Syariah Universitas Islam Lamongan \\ E-mail: averroz@gmail.com
}

\begin{abstract}
Financial institutions act as financial intermediary institutions. The activities of an activity agency can be in the form of raising funds by offering various schemes, channeling funds with various schemes or conducting activities to raise funds and channel funds at once. Such as LKS, BUS, UUS, AS, UPS, and BMT. BMT as a business institution that further delevops its business in the financial sector, namely savings and loans. BMT's product saving product include saving, time deposits, while loan products include financing, BMT financing, mudlarabah financing, musyarakah financing, murabahah financing, qardl financing, and qardl al-hasan financing. This research is a qualitative research aimed to answer questions about how the role of qard\} contract financing in BMT Mandiri Sejahtera Branch Dukun Gresik, as well as how to analyze the role of qard financing in raising the income of small and medium enterprises (UKM) to members in BMT Mandiri Sejahtera Branch Dukun Gresik. This research method using qualitative approach. Sources of data obtained from interviews, documentation, observation. Data analysis used qualitative data analysis that was inductive with descriptive approach. The results show the role of qardl contract financing in increasing the income of small and medium enterprises (UKM) to members in BMT Mandiri Sejahtera Branch Dukun Gresik. The definition of qardl financing in BMT Mandiri Sejahtera Branch of Dukun Gresik is, the provision of this financing is for small and medium business traders (UKM) who have stalls in the shaman gresik market and increase capital for small and medium enterprises (UKM). From the interviews and observation shows that there is an increase in the efforts of members who after obtaining the financing akad qardl.
\end{abstract}

Keywords: qardl, income small and medium enterprises, BMT Mandiri Sejahtera Branch of Dukun Gresik.

\section{Pendahuluan}

Seiring dengan meningkatnya tingkat kebutuhan masyarakat di Indonesia baik dari segi pangan sandang dan papan maka banyaknya pertumbuhan usaha-usaha kecil menengah di kalangan masyarakat guna memenuhi kebutuhannya masing-masing. Munculnya usaha-usaha tersebut tentu tidak terlepas dari modal dalam menjalankan kegiatannya. Dalam memperoleh 
modal maka pihak pengusaha akan mencari lembaga keuangan yang dapat membantu dalam hal pembiayaan.

Lembaga keuangan berperan sebagai lembaga intermediasi keuangan. Kegiatan usaha lembaga kegiatan dapat berupa menghimpun dana dengan menawarkan berbagai skema, menyalurkan dana dengan berbagai skema atau melakukan kegiatan menghimpun dana dan menyalurkan dana sekaligus. Lembaga Keuangan Syariah (LKS) pada saat ini tumbuh dengan cepat dan menjadi bagian dari kehidupan keuangan di dunia Islam. LKS bukan hanya terdapat di negara-negara Islam, tetapi juga terdapat di negara-negara yang ada masyarakat muslimnya. Lembaga Keuangan Syariah (LKS) yang berupa bank terdiri dari bank umum syariah (BUS) dan unit usaha syariah (UUS), sedangkan lembaga non bank antara lain berupa asuransi syariah (AS), bayt al-mal wa al-tamwil (BMT), dan unit simpan pinjam syariah (USPS).

Bayt al-mal wa al-tamwil (BMT) sebagai lembaga bisnis yang lebih mengembangkan usahannya pada sektor keuangan, yakni simpan pinjam. Produk-produk simpanan BMT antara lain berupa tabungan, deposito, sedangkan produk pinjaman berupa pembiayaan, pembiayaan pada BMT yaitu, pembiayaan mudlarabah, pembiayaan musyarakah, pembiayaan murabahah, pembiayaan qardl, dan pembiayaan qardl al-hasan.

Hal itu juga yang dilakukan oleh BMT Mandiri Sejahtera Cabang Dukun Gresik merupakan salah satu lembaga keuangan non bank yang bersedia membantu para pengusaha dalam hal permodalan yakni pembiayaan qardl. Pembiayaan qardl merupakan harta yang memiliki kesepadanan yang anda berikan untuk anda tagih kembali, atau dengan kata lain suatu transaksi yang dimaksudkan untuk memberikan harta yang dimiliki kesepadanan kepada orang lain untuk dikembalikan yang sepadan dengan itu, akad qardl berorientasi ke akad tabaru' (tolong menolong).

Akad qardl, akad yang dalam penyediaan dana pinjaman kepada pihak yang layak untuk mendapatkannya. Secara syariah peminjam hanya berkewajiban membayar kembali pokok pinjamannya, walaupun syariah membolehkan peminjam untuk memberikan imbalan sesuai kerelaannya, tetapi di BMT Mandiri Sejahtera Cabang Dukun Gresik memberi pinjaman dengan akad qardl ini tidak diperkenankan untuk meminta imbalan apapun.

Oprasional qardl ini sama seperti hutang piutang pada umumnya, akan tetapi di BMT Mandiri Sejahtera Cabang Dukung Gresik, ketika ada nasabah yang melakukan pembiayaan ini harus membayar infaq Rp. 2000 (jika nasabah ikhlas dan mempunyai uang untuk membayar infaq tersebut), dan biaya administrasi lainnya. Akad qardl hanya diberikan kepada nasabah yang benar-benar tidak mampu dalam hal ekonomi, Biasanya diberikan kepada usaha kecil menengah.

Usaha Kecil dan Menengah (UKM) merupakan salah satu bagian penting dari perekonomian suatu negara maupun daerah, begitu juga dengan negara Indonesia. UKM ini sangat memiliki peranan penting dalam lajunya perekonomian masyarakat. UKM ini juga sangat membantu Negara atau pemerintah dalam hal penciptaan lapangan kerja baru dan lewat UKM juga banyak tercipta unit-unit kerja baru yang menggunakan tenaga-tenaga baru yang dapat mendukung pendapatan rumah tangga.

Pengembangan UKM perlu mendapatkan perhatian yang besar baik dari pemerintah maupun masyarakat agar dapat berkembang lebih kompetitif bersama pelaku ekonomi lainnya. Kebijakan pemerintah ke depan perlu diupayakan lebih kondusif bagi tumbuh dan 
berkembangnya UKM. Pemerintah perlu meningkatkan peranya dalam memberdayakan UKM disamping mengembangkan kemitraan usaha yang saling menguntungkan antara pengusaha besar dengan pengusaha kecil, dan meningkatkan kualitas Sumber Daya Manusia.

BMT Mandiri Sejahtera Cabang Dukun Gresik saat ini dalam upaya memajukan usaha kecil menengah sebagai salah satu usaha yang diharapkan mampu untuk memenuhi kebutuhan keluarga dengan adanya dukungan pembiayaan dari BMT tersebut. Dalam kaitannya pembiayaan qardl, maka keberpihak BMT Mandiri Sejahtera Cabang Dukun Gresik terhadap kepentingan masyarakat menjadi sangat penting. Sesuai dengan teori syariah, atas memberi manfaat pada setiap aspek pembiayaan tercemin pada daya serap pembiayaan tersebut misalnya jumlah muncul dan berkembang.

\section{Pengertian Qardl dalam Islam}

Qardl di kalangan ahli bahasa didefinisikan sebagai berikut. Lafaz al-Qardl berarti alQath'u (memotong), قر ضه - يقر ضا , قرضه رقر ضه 'dengan harakat kasrah pada huruf ra' berarti memotongnya". ${ }^{1}$ Secara istilah adalah pemberian atau meminjamkan harta kepada orang lain yang dapat ditagih atau diminta kembali sebanyak yang dipinjamkan. Dengan demikian qardl tidak ada imbalan atau tambahan nilai pengembalian. ${ }^{2}$

Transaksi qardl diperbolehkan oleh para ulama berdasarkan hadits riwayat Ibnu Majjah dan ijma ulama. Sungguhpun demikian, Allah SWT mengajarkan kepada kita agar meminjamkan sesuatu bagi "agama Allah".

"Siapakah yang mau meminjamkan kepada Allah pinjaman yang baik, Allah akan melipat gandakan (balasan) pinjaman itu untuknya dan dia akan memperoleh pahala yang banyak". (al-Hadid: 11).

Yang menjadi landasan dalil dalam ayat ini adalah kita disuruh untuk "meminjamkan kepada Allah", artinya untuk membelanjakan harta di jalan Allah. Selaras dengan meminjamkan kepada Allah, kita juga disuruh untuk "meminjamkan kepada sesama manusia", sebagai bagian dari kehidupan bermasyarakat.

Sedangkan dalil hadis adalah Riwayat dari Ibn Mas'ud bahwa Nabi SAW berkata, "Bukan seorang muslim (mereka) yang meminjamkan muslim (lainnya) dua kali kecuali yang satunya adalah (senilai) sedekah" (HR Ibnu Majah no. 2421, kitab al-Ahkam; Ibnu Hibban dan Baihaqi).

Para ulama sendiri telah menyepakati (ijma') bahwa al-qardl boleh dilakukan. Kesepakatan ulama ini didasari tabiat manusia yang tidak bisa hidup tanpa pertolongan dan bantuan saudaranya. Tidak ada seorang pun yang memiliki segala barang yang ia butuhkan. Oleh karena itu, pinjam-meminjam sudah menjadi satu bagian dari kehidupan di dunia ini. Islam adalah agama yang sangat memperhatikan segenap kebutuhan umatnya.

Adapun rukun qardl terdiri dari muqtaridl (peminjam), muqridl (pemberi pinjaman), qardl, dan Ijab qabul. ${ }^{3}$ Sedangkan syarat qardl adalah adanya kerelaan dua pihak melakukan akad, dan dana yang akan digunakan ada manfaat dan halal. ${ }^{4}$

\footnotetext{
${ }^{1}$ Imam Mustofa, Fiqih Mu'amalah Kontemporer (Jakarta: PT Raja Grafindo Persada, 2016), 167.

2 Atang Abd. Hakim, Fiqih Perbankan Syariah (Bandung: PT Refika Aditama, 2011), 266.

${ }^{3}$ Muhammad Yusuf, Bisnis Syariah (Jakarta: Mitra Wacana Media, 2011), 138.
} 


\section{Aplikasi qardl dalam Lembaga Keuangan Syariah (LKS)}

Qardl sebagai salah satu landasan transaksi produk pembiayaan perbankan syariah mengacu kepada UU no 21 tahun 2008 pasal layat (25) huruf d, pasal 19 ayat (1) dan (2) huruf e, dan pasal 21 huruf b angka 3. Menurut UU ini, al-qardl di artikan sebagai "akad pinjaman dana kepada nasabah dengan ketentuan bahwa nasabah wajib mengembalikan dana yang diterimanya pada waktu yang telah disepakati”.

Produk pembiayaan al-qardl merupakan salah satu sisi efisiensi lembaga keuangan syariah dibandingkan dengan lembaga keuangan konvensional. Teori qardl memberikan peluang kepada nasabah untuk memanfaatkan produk pembiayaan dengan transaksi qardl. Produk ini berupa transaksi kredit pembiayaan dalam bentuk pinjaman dan tanpa imbalan. Artinya lembaga keuangan tersebut tidak mensyaratkan nasabah untuk mengembalikan pinjamannya melibihi jumlah nominal dana yang dipinjamnya termasuk biaya administrasi.

Dalam terminologi fiqih muamalah, sistem yang diterapkan di Lembaga Keuangan Syariah ini disebut teori qardl al-hasan. Teori mengatakan, bahwa yang meminjamkan tidak mengharapkan kebaikan kecuali dari Allah SWT bukan dari kelebihan pengembalian pinjaman nasabah, adapun pinjaman yang mensyaratkan adanya kelebihan pengembalian adalah riba. Akad qardl biasanya diterapkan sebagai produk pelengkap kepada nasabah yang telah terbukti loyalitas dan bonafiditasnya. Yang membutuhkan dana talangan segera untuk masa yang relatif pendek. Nasabah tersebut akan mengembalikan secepatnya sejumlah uang yang dipinjamnya itu. Selain itu juga sebagai fasilitas nasabah yang memerlukan dana cepat, sedangkan ia tidak bisa menarik dananya karena, misalnya, tersimpan dalam bentuk deposito. Sebagai produk untuk menyumbang usaha yang sangat kecil atau membantu sektor sosial. Guna pemenuhan skema khusus ini telah dikenal suatu produk khusus, yaitu al-qardl alhasan. 5

Praktik qardl pada lembaga keuangan syariah dapat dijelaskan sebagai berikut:

1. Nasabah mengajukan pinjaman dana qardl kepada Lembaga Keuangan Syariah (LKS).

2. Nasabah dan pihak Lembaga Keuangan Syariah (LKS) menyepakati mengenai biaya administrasi dan waktu pengembalian pinjaman.

3. Lembaga Keuangan Syariah (LKS) dapat meminta jaminan atas pinjaman apabila diperlukan.

4. Nasabah menggunakan dana pinjaman tersebut untuk usaha.

5. Apabila mendapat keuntungan dari usaha tersebut, maka seluruhnya menjadi hak nasabah, apabila terjadi kerugian, maka juga menjadi tanggung jawab nasabah.

6. Nasabah harus mengembalikan pinjaman sejumlah nominal yang dipinjam, tanpa harus memberikan margin atau bunga.

7. Pasal 616 KHES menyebutkan bahwa jika nasabah dapat memberikan tambahan atau sumbangan dengan suakrela kepada pemberi pinjaman selama tidak diperjanjikan dalam transaksi.

8. Pasal 616 KHES menyebutkan bahwa jika nasabah tidak dapat mengembalikan sebagian atau seluruh kewajiban pada saat yang telah disepakati dan pemberi pinjaman Lembaga

\footnotetext{
${ }^{4}$ Ibid., 139.

${ }^{5}$ Muhammad Syafi'i Antonio, Bank Syariah dari Teori ke Praktik (Jakarta: Gema Insani, 2001), 133.
} 
Keuangan Syariah (LKS) telah memastikan ketidak mampuannya, maka LKS dapat memperpanjang jangka waktu pengembalian atau menghapus (write off) sebagian atau seluruh kewajibannya

\section{Peran Penting Usaha Kecil Menengah (UKM)}

Usaha Kecil Menengah (UKM) menurut Departemen perindustrian dan Bank Indonesia mendefinisikan usaha kecil berdasarkan nilai asetnya, yaitu suatu usaha yang asetnya (tidak termasuk tanah dan bangunan) bernilai kurang dari Rp. 600 juta. Sedangkan departemen perdagangan mendefinisikan usaha kecil sebagai usaha yang modal kerjanya kurang dari Rp. 25 juta. Menurut Badan Pusat Statistik (BPS), industri kecil adalah usaha industri yang melibatkan tenaga kerja antara 5 sampai dengan 19 orang. Sedangkan industri rumah tangga adalah industri yang mempkerjakan kurang dari 5 orang.

Dalam perspektif perkembangannya, UKM dapat diklasifikasikan menjadi empat kelompok. Pertama, livelihood activities yang merupakan UKM yang digunakan sebagian kesempatan kerja untuk mencari nafkah, yang lebih umum dikenal sebagai sektor informal. Contohnya adalah pedagang kaki lima. Kedua, micro enterprise, merupakan UKM yang memiliki sifat pengrajin tetapi belum memiliki sifat kewirausahaan. Ketiga, small dynamic enterprise, merupakan UKM yang telah memiliki jiwa kewirausahaan dan mampu menerima pekerjaan subkontrak dan ekspor. Keempat, fast moving enterprise, merupakan UKM yang telah memiliki jiwa kewirausahaan dan akan melakukan transformasi menjadi usaha besar.

Untuk ciri-ciri UKM sendiri bisa dilihat dari:

1. Bahan baku yang mudah diperoleh.

2. Menggunakan teknologi sederhana sehingga mudah dilakukan alih teknologi.

3. Keterampilan dasar umumnya sudah dimiliki secara turun temurun.

4. Bersifat padat karya atau menyerap tenaga kerja yang cukup banyak.

5. Peluang pasar cukup luas, sebagian besar produknya terserap di pasar lokal atau domestik dan tidak tertutup sebagian lainnya berpotensi untuk diekspor.

6. Melibatkan masyarakat ekonomi lemah setempat, secara ekonomis menguntungkan.

Adapun peran penting UKM dalam perekonomian nasional adalah:

1. Sebagai pemeran utama dalam kegiatan ekonomi.

2. Penyedia lapangan kerja tersebar.

3. Pemain penting dalam mengembangan perekonomian lokal dan pemberdayaan masyarakat.

4. Pencipta pasar baru dan sumber inovasi.

5. Kontribusinya terhadap neraca pembayaran.

Oleh karena itu pemberdayaannya harus dilakukan secara testruktur dan berkelanjutan, dengan arah peningkatan produktivitas dan daya saing, serta menumbuhkan wirausahaan baru yang tangguh.

Salah satu keunggulan UKM adalah ia terkadang sangat lincah mencari beruang untuk berinovasi untuk menerapkan teknologi baru ketimbang perusahaan-perusahaan besar yang telah mapan. Tak mengherankan jika dalam era persaingan global saat ini barang kali yang bergantung pada pemasok-pemasok kecil menengah. Sesungguhnya ini peluang bagi kita untuk turut berkecimpung di era global sekaligus menggerakkan sektor ekonomi rill. 


\section{Peran Pembiayaan Qardl dalam Meningkatkan Pendapatan Usaha Kecil Menengah (UKM) pada Anggota BMT Mandiri Sejahtera Cabang Dukun Gresik}

Pembiayaan dengan menggunakan akad qardl di BMT Mandiri Sejahtera yang terletak di Desa Karangcangkring Kecamatan Dukun Kabupaten Gresik sudah ada sejak berdirinya BMT tersebut. Akan tetapi pembiayaan qardl di BMT Mandiri Sejahtera Cabang Dukun Gresik mulai digunakan sejak pada tahun 2010 sampai sekarang.

Qardl menurut BMT, Produk ini adalah produk pelengkap di KJKS / BMT yang di pergunakan untuk pinjaman Usaha Kecil Menengah (UKM) di pasar. Aplikasi qardl dalam BMT meminjami dana kepada anggota tanpa adanya tambahan biaya apapun, kecuali biaya administrasi langsung dalam batas kewajaran.

Sedangkan qardl secara terminologi, berarti menyerahkan harta kepada orang yang menggunakannya untuk dikembalikan gantinnya pada suatu saat. Qardl merupakan transaksi yang diperbolehkan oleh syariah dengan menggunakan skema pinjam-meminjam. Akad qardl merupakan akad yang memfasilitasi transaksi peminjam sejumlah dana tanpa adanya pembebanan bunga atas dana yang dipinjam oleh nasabah. Transaksi qardl pada dasarnya merupakan transaksi yang bersifat sosial, karena tidak diikuti dengan pengambilan keuntungan dari dana yang dipinjamkan.

Akad qardl adalah bentuk kontrak yang sifatnya saling tolong menolong antara dua pihak di mana pihak berperan sebagai pemilik modal dan mempercayakan sejumlah modalnya untuk dikelola oleh pihak kedua. Dalam qardl sebagian besar anggota mengerti tentang qardl, karena dalam qardl adanya sistem pembinaan anggota karena adanya pembinaan qardl memang lebih memantau perkembangan pengelolaan usahanya dari pada jumlah anggota dengan pembiayaan besar atau kecil.

BMT Mandiri sejahtera Cabang Dukun Gresik sebagai Lembaga Keuangan syariah yang tidak perna lepas dari masalah pembiayaan. Bahkan BMT Mandiri Sejahtera Cabang Dukun Gresik ini tidak lepas dari kegiatan saling tolong menolong. Pemberian pembiayaan adalah kegiatan utamanya, pembiayaan yang diberikan untuk menambah modal usaha sangat mempengaruhi pendapatan yang dihasilkan oleh pengusaha.

Dari pihak BMT Mandiri Sejahtera Cabang Dukun Gresik selalu ada pendampingan setiap hari ada salah satu anggota BMT yaitu marketing terjun ke pasar atau ke lapangan untuk mengontrol nasabah yang menabung, dan melihat perkembangan anggota jadi, setiap hari anggota bertemu pihak BMT, pihak BMT mengetahui perkembangan usaha anggota seperti apa, dan setiap pengajuan anggota ditanyai pendapatan perharinya berapa, jika pendapatan prospek usahanya tidak beranjak maka pinjamanya tidak dinaikan terlalu besar, 
kecuali memang usahanya lebih besar, mengajukan pembiayaan modal besar juga prospeknya harus bagus, dari pihak BMT tidak masalah untuk menyesuaikan perputaran anggota dan nilai-nilai pinjaman. Adapun syarat-syarat anggota jualan di pasar yaitu:

1. Anggota yang punya lapak di pasar.

2. Anggota menabung di BMT dengan tabungan minimal Rp. 300.000,- itu dapat pinjaman Rp. 1. 000.000.000,- jika mengajukan pembiayaan maka naik menjadi Rp. 2.000.000,minimal tabungan anggota harus ada Rp. 600.000,- nanti tabungan tersebut diblokir dari pihak BMT sebagai jaminan di BMT, sewaktu-waktu jika sudah dilunasi bisa diambil tabungan tadi. Yang penting Rp. 300.000,- untuk pembiayaan Rp. 1.000.000,-.

Peran pembiayaan akad qardl dalam meningkatkan pendapatan Usaha Kecil Menengah (UKM) pada anggota di BMT Mandiri Sejahtera Cabang Dukun Gresik. Dari segi pembiayaan akad qardl mempunyai peran yang aktif, setiap individu mempunyai kedudukan yang sama dalam memperoleh pembiayaan akad qardl. Ajaran Islam tidak hanya menetapkan ditegakkanya keadilan yang menjamin untuk kesamaan hak, tetapi lebih dari itu ditetapkan juga terlaksanaanya kajian terutama terhadap sesama, baik secara fisik maupun secara ekonomi.

Adapun peran pembiayaan akad qardl di BMT Mandiri Sejahtera Cabang Dukun Gresik adalah menambah modal usaha, meningkatkan pendapatan usaha, memenuhi kebutuhan, tanpa keuntungan margin dan ujrah, dan membantu masalah modal usaha.

Di sinilah BMT Mandiri Sejahtera Cabang Dukun Gresik sebagai Lembaga Keuangan Syariah. Pembiayaan qardl adalah salah satu cara untuk membantu masalah modal bagi Usaha Kecil Menengah (UKM), karena qardl ini adalah pinjaman tanpa tambahan apapun, karena pembiayaan untuk Usaha Kecil Menengah (UKM) yang pinjaman bisa mulai Rp. 500.000,sampai Rp. 5.000.000,-, akad qardl ini untuk pedagang pasar yang punya lapak-lapak, pedagang jualan kerupuk dan lain sebagainya. Dalam peraktek di lapangan, qardl itu menyalurkan dananya untuk Usaha Kecil Menengah (UKM) yang membutuhkan modal usaha untuk meningkatkan pendapatan usahanya.

Selain meningkatkan usaha anggota, juga ada upaya untuk menyelesaikan persoalanpersoalan dari pihak anggota mempunyai tanggungan di bank-bank lainya (bank harian), dengan adanya program qardl ini misi pihak BMT tersebut, sebenarnya qardl ini selain meningkatkan pendapatan usaha dan menuntaskan dari bank-bank harian, makanya pinjaman akad qardl ini tanpa jaminan, tanpa ujrah, tanpa apapun cuma membayar administrasi di awal yang sebesar Rp. 10.000,- dan anggota mau menabung di BMT setiap hari atau pasaran. 
Di sinilah peran BMT Mandiri Sejahtera Cabang Dukun Gresik sebagai lembaga mal untuk peduli masalah anggota. Pembiayaan qardl adalah salah satu cara untuk membantu masalah modal bagi pengusaha kecil, karena pembiayaan qardl ini adalah pinjaman tanpa tambahan apapun, karena pembiayaan ini anggotanya adalah masyarakat yang termasuk golongan lemah, dalam prateknya di lapangan qardl tidak hanya menyalurkan dananya untuk anggota melainkan juga membantu anggota untuk meningkatkan pendapatan usaha anggota.

Pemberian dana dari pembiayaan qardl ini memang dikatakan masih sedikit dari beberapa pembiayaan yang lain, akan tetapi anggota ini sangat menanti pembiayaan qardl dari BMT tersebut, karena pembiayaan qardl ini menambah modal dan juga kebutuhan keluarga, anggota tidak memiliki modal akan tetapi mempunyai skill dan tenaga kerja. Dari hasil wawancara dengan para anggota yang menggunakan pembiayaan qardl, adanya pembiayaan qardl artinya adanya peningkatan pendapatan mereka dalam produksi.

Dengan adanya pembiayaan akad qardl yang dilaksanakan oleh BMT Mandiri Sejahtera Cabang Dukun Gresik yang salah satu misinya adalah meningkatkan pendapatan Usaha Kecil Menengah (UKM) pada anggota di BMT tersebut dapat dikatakan berhasil. Dan penanggunan seluruh kegiatan usaha dilakukan oleh anggota BMT Mandiri Sejahtera cabang Dukun Gresik sebagai penyedia modal tidak akan mencampuri manajemen usaha, tetap mempunyai hak untuk melakukan kontrol atau pengawasan. Dalam hal ini sangat diperlukan penguasaan dan pemahaman atas karakteristik resiko usaha anggotanya, akan semakin ketat pengawasan dan kontrol yang harus dilakukan oleh pihak BMT guna untuk mengantisipasi hal-hal yang tidak diinginkan terjadi.

Pada dasarnya untuk tamwil didominasikan oleh pembiayaan-pembiayaan yang menguntungkan, untuk pembiayaan qardl di BMT Mandiri Sejahtera Cabang Dukun Gresik ini prosentasinya sangat kecil. Namun harapan BMT Mandiri Sejahtera Cabang Dukun Gresik berperan dimasyarakat, minimal peduli dengan apa yang dirasakan oleh kaum umat. Selain itu harapan dari BMT Mandiri Sejahtera Cabang Dukun Gresik menjadi unggulan, bisa membuka pintu berkah bersifat tolong menolong, dengan sistem tolong menolong BMT Mandiri Sejahtera Cabang Dukun Gresik membantu sejumlah anggota untuk memberikan bantuan modal usahanya untuk membeli sejumlah barang-barang untuk dibuat usahanya, tidak tanggung-tanggung BMT Mandiri Sejahtera Cabang Dukun Gresik memberikan itu semua secara cuma-cuma.

Pembiayaan akad qardl yang dijalankan oleh pihak BMT Mandiri Sejahtera Cabang Dukun Gresik diberikan BMT kepada para anggota yang mempunyai Usaha Kecil Menengah (UKM) mereka terbantu untuk kehidupannya, diantaranya untuk tambahan modal usaha 
kecilnya dan meningkatkan pendapatan usahanya. Pembiayaan akad qardl yang berasal dari BMT Mandiri Sejahtera Cabang Dukun Gresik adalah tidak berbunga, tanpa ujrah, prinsip tolong menolong dan berlandasan hukum al-Quran, hadist dan ijma. Dan diharapkan dapat mendorong pengusaha kecil menengah untuk dapat meningkatkan produksinya sehingga meningkatkan pendapatan dan mampu bersaing dengan penggusaha lainnya.

\section{Penutup}

Berdasarkan pembahasan di atas, maka dapat disimpulkan bahwa pertama, peran Pembiayaan qardl di BMT Mandiri Cabang Dukun Gresik menjelaskan bahwa pembiayaan akad qardl mempunyai peran yang aktif, setiap individu dan mempunyai kedudukan yang sama dalam memperoleh pembiayaan akad qardl. Produk ini pelengkap di KJKS/BMT yang dipergunakan untuk pinjaman Usaha Kecil Menengah (UKM) di pasar. Peran pembiayaan akad qardl di BMT Mandiri Sejahtera Cabang Dukun Gresik sebagai Lembaga Keuangan Syariah yang tidak perna lepas dari masalah pembiayaan. Bahkan BMT Mandiri Sejahtera Cabang Dukun Gresik ini tidak perna lepas dari kegiatan tolong menolong. Pembiayaan akad qardl adalah kegiatan utamanya, pembiayaan yang diberikan untuk menambah modal usaha sangat mempengaruhi pendapatan yang dihasilkan oleh pengusaha.

Kedua, peran pembiayaan akad qardl dalam meningkatkan pendapatan Usaha Kecil Menengah (UKM) pada anggota di BMT Mandiri Sejahtera Cabang Dukun Gresik menjelaskan bahwa akad qardl adalah pinjaman uang atau modal yang diberikan seseorang kepada pihak yang lainnya, di mana pinjaman tersebut digunakan untuk usaha atau menjalankan bisnis tertentu. Adapun peran pembiayaan akad qardl untuk menambah modal Usaha Kecil Menengah (UKM) tersebut dibiayai dari pihak BMT dengan pinjaman akad qardl untuk menambah modal usahanya dan meningkatkan pendapatan usahanya. Selain untuk meningkatkan usaha anggota, juga ada upaya untuk menyelesaikan persoalan-persoalan yang ada di anggota. Pembiayaan akad qardl yang dilaksanakan oleh BMT Mandiri Sejahtera Cabang Dukun Gresik yang salah satu misinya adalah meningkatkan pendapatan Usaha Kecil Menengah (UKM) pada anggota tersebut dapat dikatakan berhasil. Pembiayaan akad qardl yang berasal dari BMT Mandiri Sejahtera Cabang Dukun Gresik adalah tidak berbunga, tanpa ujrah, prinsip tolong menolong dan berlandasan al-Quran, hadist dan ijma.

\section{Daftar Rujukan}

Antonio, Muhammad, Syafi'i, Bank Syariah dari Teori ke Praktik Jakarta: Gema Insani, 2001. 
BN. Marbun. Kamus Manajemen. Jakarta: Pustaka Sinar Harapan, 2003.

Departemen Pendidikan dan Kebudayaan. Kamus Besar Bahasa Indonesia. Jakarta: pustaka, 1997.

Hakim, Atang, Abd.Fiqih Perbankan Syariah. Bandung: PT Refika Aditama, 2011.

Mustofa, Imam. Fiqih Mua'amalah Kontomporer. Jakarta:PT Raja Grafindo Persada, 2016.

Sari, Oktavia, Dia. "Pengaruh Pemberian Pembiayaan Modal Kerja Terhadap Peningkatan Pendapatan Usaha Nasabah Bank BTN Syariah Palembang” (Skripsi--Universitas Raden Fatah Palembang, 2017).

Yusuf, Muhammad. BisnisSyariah. Jakarta: Mitra Wacana Media, 2011. 